Article

\title{
Does "Greening" of Neotropical Cities Considerably Mitigate Carbon Dioxide Emissions? The Case of Medellin, Colombia
}

\author{
Carley C. Reynolds ${ }^{1}$, Francisco J. Escobedo ${ }^{2}$, Nicola Clerici ${ }^{2, *}$ and Jorge Zea-Camaño ${ }^{3}$ \\ 1 Nicholas School of the Environment, Duke University, Environment Hall, 9 Circuit Drive, Durham, \\ NC 27708, USA; carley.reynolds@duke.edu \\ 2 Programa de Biología, Facultad de Ciencias Naturales y Matemáticas, Universidad del Rosario, \\ Cr. 24 No 63C-69, Bogotá, Colombia; franciscoj.escobedo@urosario.edu.co \\ 3 Programa de pós Graduação em Engenharia Florestal, Universidade Federal do Paraná, \\ Av. Pref. Lothário Meissner, 632, CEP: 80210-170 Curitiba, Paraná, Brazil; jdzeaca@gmail.com \\ * Correspondence: nicola.clerici@urosario.edu.co; Tel.: +57-1297-0200 (ext. 4024)
}

Academic Editor: Davide Geneletti

Received: 30 January 2017; Accepted: 2 May 2017; Published: 9 May 2017

\begin{abstract}
Cities throughout the world are advocating highly promoted tree plantings as a climate change mitigation measure. Assessing the carbon offsets associated with urban trees relative to other climate change policies is vital for sustainable development, planning, and solving environmental and socio-economic problems, but is difficult in developing countries. We estimated and assessed carbon dioxide $\left(\mathrm{CO}_{2}\right)$ storage, sequestration, and emission offsets by public trees in the Medellin Metropolitan Area, Colombia, as a viable Nature-Based Solution for the Neotropics. While previous studies have discussed nature-based solutions and explored urban tree carbon dynamics in high income countries, few have been conducted in tropical cities in low-middle income countries, particularly within South America. We used a public tree inventory for the Metropolitan Area of the Aburrá Valley and an available urban forest functional model, i-Tree Streets, calibrated for Colombia's context. We found that $\mathrm{CO}_{2}$ offsets from public trees were not as effective as cable cars or landfills. However, if available planting spaces are considered, carbon offsets become more competitive with cable cars and other air quality and socio-economic co-benefits are also provided. The use of carbon estimation models and the development of relevant carbon accounting protocols in Neotropical cities are also discussed. Our nature-based solution approach can be used to better guide management of urban forests to mitigate climate change and carbon offset accounting in tropical cities lacking available information.
\end{abstract}

Keywords: climate change mitigation; nature-based solutions; urban forest; carbon offsets; clean development mechanism; street trees; ecosystem services

\section{Introduction}

In 2015, the global population reached 7.3 billion with an increase of about 1 billion in the last twelve years alone [1]. According to the United Nations [2], the proportion of the population living in urban areas is expected to increase from $54 \%$ to $66 \%$ by 2050 . This proportion of urban inhabitants is even greater in Latin America and the Caribbean, where approximately $80 \%$ of the population already resides in urban areas [2].

Policies and activities to address climate change in tropical Latin American countries generally focus on mitigating carbon emissions from the industrial and transportation sectors [3]. In Brazilian and Colombian cities, innovative transportation policies and programs have been reported as effective policies to mitigate local-scale anthropogenic carbon dioxide $\left(\mathrm{CO}_{2}\right)$ emissions [3]. In Medellin, 
Colombia, the use of cable cars that reach less accessible, low income neighborhoods have been touted as measures that both promote social inclusion and provide other co-benefits such as offsets of carbon emissions [4,5]. Similarly, the role of deforestation and forest degradation in global-scale anthropogenic $\mathrm{CO}_{2}$ emissions has been well established in the environmental literature, particularly for tropical forests [6]. However, less is known about the influence of existing urban forests, deforestation in peri-urban areas, and commonly touted urban tree planting programs and their role in local-level $\mathrm{CO}_{2}$ regulation in cities such as those from Neotropical Latin America [7]. Indeed, urban areas worldwide play a major role, accounting for $71-76 \%$ of energy related $\mathrm{CO}_{2}$ emissions [8].

While many different strategies at the national and local-level are needed to address increasing greenhouse gases emissions, local-level nature-based solutions can play an important role in mitigating local and regional urban environmental quality issues, not only in cities in high income countries, but also in low-middle income countries such as Colombia [9-11]. These nature-based solutions have recently been proposed in Europe as not only an approach for addressing climate change, but also for creating employment opportunities and a green economy [12,13]. Unfortunately, to our knowledge the concept has been little discussed outside the European Union and the United States [13]. However, such approaches are arguably more important in cities in regions such as Latin America, rather than in Europe, due to the marked socio-economic disparities and high proportion of vulnerable populations. The use of urban and peri-urban forests and agriculture, for example, are solutions that could also be used for improving urban air quality and food security, reducing temperatures, conserving biodiversity, maintaining water quality, and increasing employment through tree maintenance and green space management [12-15].

Urban trees directly remove $\mathrm{CO}_{2}$ from the atmosphere through sequestration, and can reduce building cooling demands through shading and evapotranspiration, thus indirectly reducing $\mathrm{CO}_{2}$ emissions from the use of fossil fuels to produce energy for building cooling [16]. Additionally, herbaceous vegetation and soils contribute to carbon sequestration and storage, and provide numerous other ecosystem services such as atmospheric pollution removal, biodiversity, and storm water regulation [17-19]. However, in addition to these benefits, urban trees can generate costs or ecosystem disservices, by incurring maintenance and management costs, production of allergenic pollen, and can lead to $\mathrm{CO}_{2}$ emissions through decomposition, soil respiration, and maintenance-related fossil fuel burning activities $[17,20]$; as such, these types of costs and emissions must also be accounted for.

Understanding the $\mathrm{CO}_{2}$ offset potential and effectiveness of urban tree plantings can help determine and promote their viability as a nature-based solution. A characterization and framework for nature-based solutions that includes an assessment of multiple co-benefits for the urban Neotropics is warranted. Such assessment would require the accurate estimates of benefits, one of which is carbon sequestration [21].

Improving carbon estimates would also improve the incorporation of urban tree plantings into carbon markets and climate policy. In December 2015, the United Nations Framework Conference on Climate Change (UNFCCC) produced the 2015 Paris Agreement. As a country party to the convention, Colombia submitted their new emissions target, committing to reductions of $20 \%$ below business as usual emissions by 2030, or 30\% below business as usual with sufficient international support [22]. One mechanism for high income countries to provide this support to Colombia is through the Clean Development Mechanism (CDM) [23]. This mechanism allows developed countries to invest in offset projects in developing countries in exchange for certified emissions reduction credits [23]. The CDM accounting methodologies for receiving credits for a project must either be developed or adopted from a past project and approved.

From 2008 to 2012, a methodology for accounting for $\mathrm{CO}_{2}$ sequestration from urban afforestation/reforestation, AR-AMS0002, was in effect, but is since inactive [23]. Currently, AR-AMS0002 does not account for avoided emissions from cooling or emissions from tree maintenance or plantings, only net sequestration [24]. However, a carbon offset registry with associated protocols has recently been developed for urban forest projects [25]. 
Previous studies in temperate high income regions of the world have looked at the potential of urban trees to offset $\mathrm{CO}_{2}$ at multiple scales. In the US, national-level carbon storage and sequestration by urban trees was evaluated [26], as well as state level urban forest carbon sequestration [18]. Other authors have reported city-scale carbon sequestration by urban forests and public trees in several US and Chinese cities [16,19,27-29]. More recently, $C$ storage and sequestration by urban trees in European cities such as Barcelona, Bolzano, Rome, and elsewhere are increasingly being studied [17,30-32]. A study much closer to Medellin estimated average carbon stocks per tree for Bogota, Colombia's public urban forests [9].

Some studies have also investigated management, maintenance, and socio-ecological dynamics and the interaction between urban tree carbon sequestration and emissions $[20,27,33]$. Another body of research is exploring if the use of trees is indeed an effective policy and activity to mitigate local $\mathrm{CO}_{2}$ emissions [14,16,17,28,34,35]. In terms of policy effectiveness, studies in the United States have documented that local level reforestation of degraded peri-urban areas can cost effectively be used to improve air quality while providing other co-benefits, such as $\mathrm{CO}_{2}$ sequestration and wildlife habitat [36].

Another study found that urban tree plantings "may be cost-effective" in certain locations in the US [15]. However, a different study found that urban forest management was "moderately" effective as a mitigation strategy in two cities in Florida, USA, relative to other reduction strategies [14]. Similarly, studies in Europe raise awareness to the fact that different urban tree and vegetation carbon calculation methods, such as the choice of allometric equations, carbon estimation models, resolution of geospatial data, and reporting of different carbon pools (i.e., above ground versus below ground carbon pools) will yield very different $C$ sequestration results $[17,32]$.

While the above studies have mostly analyzed cities in the US, Europe, and China, few have explored the use of trees as a nature-based solution for climate change mitigation in Neotropical cites and low-middle income countries. Assessments and studies have, however, looked at the use of innovative transportation strategies and policies to offset $\mathrm{CO}_{2}$ emission in Latin American countries, such as in Colombia [4,5]. The need for other innovative measures (i.e., nature-based solutions) is necessary as a response to Colombia's projected rates of urbanization and population vulnerable to adverse climate change effects [5].

This study aims to develop an approach for assessing the potential use of public trees in Neotropical cities to offset $\mathrm{CO}_{2}$ emissions where there is often a lack of data and information. Specifically, the objectives of this study are to: (1) estimate carbon storage and sequestration by public trees in the urban area of the MAAV (Metropolitan Area of the Aburrá Valley); (2) estimate the relative $\mathrm{CO}_{2}$ emissions offset potential by the MAAV's public trees; and (3) discuss the effect that proposed large scale tree planting can have on \#1 and \#2.

\section{Materials and Methods}

\subsection{Study Area and Inventory Data}

The study area is Medellin and more specifically the Metropolitan Area of the Aburrá Valley (MAAV), Colombia. The MAAV is part of the Department of Antioquia and encompasses the municipalities of Medellin, Bello, Barbosa, Copacabana, La Estrella, Girardota, Itagüí, Envigado, Caldas, and Sabaneta. The urban zone of the MAAV resulted from the conurbation of the municipalities' town centers with Medellin at its center [37]. This area is the second most populated metropolitan area in Colombia, with a population over 3 million [37]. While the MAAV represents only $2 \%$ of the land area of the Department of Antioquia, it accounts for over 65\% of the population [37]. The proportion of the Colombian population living in urban areas increased from $57 \%$ to $71 \%$ from 1970 to 2000 and is expected to reach $85 \%$ by 2050 [3].

The MAAV extends approximately $60 \mathrm{~km}$ along the Medellin River and covers $1152 \mathrm{~km}^{2}$ [37]. The urban zone of the MAAV, however, covers $118 \mathrm{~km}^{2}$ [37] (Figure 1). The MAAV is located at 
about $1500 \mathrm{~m}$ above sea level, and it corresponds to Premontane moist forest (bh-PM) according to the Holdridge's Lifezones classification [38]. The precipitation is characterized by a bi-modal distribution, with an average annual value in the city of $1687 \mathrm{~mm}$, while the average high and low annual temperatures are $28^{\circ} \mathrm{C}$ and $17^{\circ} \mathrm{C}$, respectively [39].

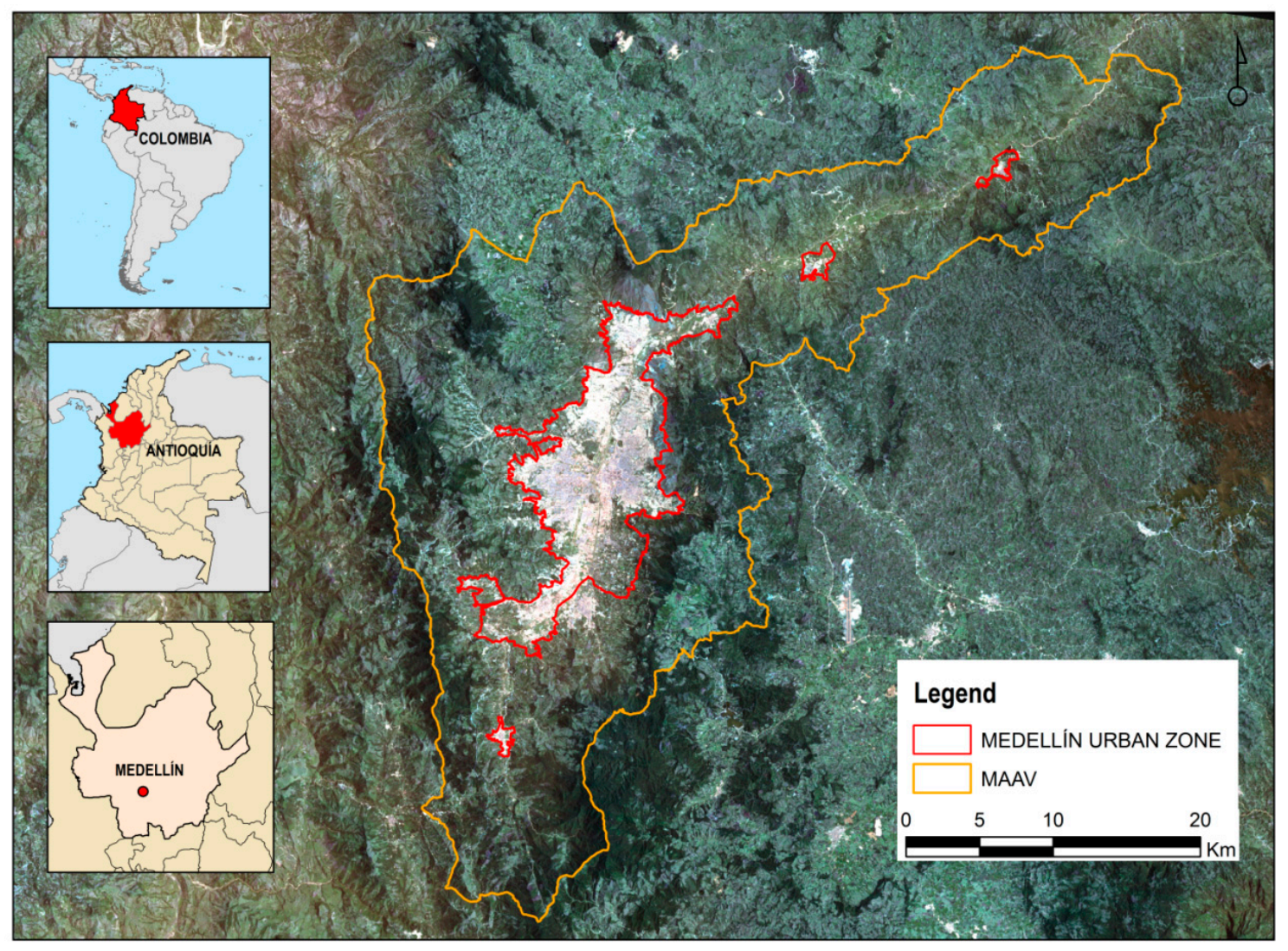

Figure 1. The Metropolitan Area of the Aburrá Valley (MAAV) and associated Medellín urban zone, Departamento de Antioquía, Colombia. Background image: Landsat 8 OLI.

In 2007, the Aburrá Valley Urban Environmental Authority implemented the Urban Green Spaces Master Plan for the MAAV as the main policy instrument to manage its vegetation [39]. This study used a complete inventory of all public trees compiled as part of the Master Plan. For this study, we define "public trees" as those trees located in all public areas, such as parks, front lawns, road corridors, sidewalks, road medians, as well as stream and river courses. The inventory originally consisted of 406,856 trees and shrubs, but was filtered to only include trees with (i) a Diameter at Breast Height (DBH) greater than $2.5 \mathrm{~cm}$ and (ii) a total height more than $2 \mathrm{~m}$, resulting in 182,044 public trees, following [9]. Additionally, 352 trees were removed since they did not report any species data. The final inventory had 181,693 trees representing 358 different species. The inventory covered approximately $21.53 \mathrm{~km}^{2}$ of public green spaces in the urban zone of the MAAV $\left(118.22 \mathrm{~km}^{2}\right)$ [39].

\subsection{Modeling Carbon Sequestration and Co-Benefits}

Studies in Portugal and the United States have used i-Tree Streets, a model developed by the United States Department of Agriculture (USDA) Forest Service, to assess costs and benefits associated with urban trees [40,41]. The modeling approach behind the i-Tree-Streets model is based on 16 reference cities of the United States that represent 16 different climate zones (please see Figure 1 in [40]). For each reference city, 30-70 trees for each of the 19-22 of the most common tree species were sampled and measured [40]. Using these measurements, best-fit allometric equations were used to 
model crown diameter, leaf surface area, and height as a function of a tree's size or a tree's diameter at breast height, or $1.3 \mathrm{~m}$ above the surface (DBH) [40,41].

Thus, the i-Tree-Streets model assumes that cities from the same reference zone will have comparable tree species with similar growth and mortality traits [40]. Accordingly, for each reference zone individuals from the most common species are measured for $\mathrm{DBH}$ and other metrics and then the tree planting dates are determined or cross dating of tree rings is used for each of these measured individuals and linear regressions are used to predict DBH as a function of age for each sampled species [40]. The i-Tree Streets model then applies a series of functions, using a tree's DBH and species or tree type, to estimate tree volume [42]. The aboveground dry-weight biomass is then derived from the estimated tree volume and wood density. Results are then adjusted to include below-ground biomass using a root-to-shoot ratio of 0.26 and are converted to $\mathrm{CO}_{2}$ equivalent by multiplying by 3.67. This same data, allometric equations, and environmental characteristics from each selected reference city are also used to estimate other co-benefits such as air quality improvement, stormwater mitigation, and property value effects [40]. Other studies provide further background on the necessary modeling parameterization and calibration requirements $[40,41]$. Based on its use in other cities and its relevance to the stated objectives of our study, we applied this modelling approach to estimate annual $\mathrm{CO}_{2}$ reductions from both sequestration by trees and $\mathrm{CO}_{2}$ emissions avoided from energy use through microclimate regulation in Medellin [42].

To assign our modeling domain to a reference climate condition as required in the i-Tree Streets model, we used a systematic approach for selecting the best reference city [40]. This method assessed four different criteria from each reference city to determine the closest match to MAAV: heating degree days (HDD), cooling degree days (CDD), annual precipitation, and tree species match. The HDD value represents how much building heating is needed by calculating how much and for how long outside temperatures are below a chosen base temperature. Similarly, CDD represents how much building cooling is needed by calculating how much and for how long outside temperatures are above the baseline. The first three criteria (HDD, CDD, and annual precipitation) are listed for each reference city [40]. Tree species match, however, must be determined by comparing the species composition of the subject city to the species composition of each reference city.

Because of the importance of tree species for $\mathrm{CO}_{2}$ estimates, two methods were used to find and compare a similar tree species composition match for Medellin. The first method was based on the previous study [40], and accordingly we compared the most common tree species in the MAAV inventory to the 19-22 species sampled and measured for each i-Tree Streets reference city. The number of each species that matched with the most common MAAV species on the genus or species level were summed. However, matching MAAV's most common species with only the 19-22 most common species for each US reference city can skew the selection process.

Accordingly, the second method for determining tree match accounts for all species in the study area and reference city's inventories, and their abundance. Overall, we found more tree species were matched with Honolulu (Tropical region), Orlando (Central Florida, Orlando, FL, USA), and Santa Monica (Southern California, CA, USA), rather than with Modesto (Inland Valley region). The total number of tree species in the MAAV inventory that had a similar species or genus to the Tropical and Inland Valley region were 121 and 29, respectively. To account for abundance, individuals for each matched species for each region were summed. Overall 128,635 (71\% of the total inventory) individual trees in the MAAV inventory matched with Honolulu as the reference city, while only 21,093 (12\%) matched using Modesto as the reference city. Tree match results for both methods for all four comparable reference cities are shown in Appendix A. Because this study's objective is focused on carbon storage and sequestration, we used this second method since tree carbon is a function of a tree's species, size, and other characteristics [13]. The criteria values (Appendix A) [40] were then normalized to allow for direct comparison among all listed criteria.

This normalization consists of first finding the range of values for each criterion listed across the reference cities. Each range was then divided into 10 equal intervals assigned a value $0-10$. Next, the 
difference value for each criterion for each reference city was found by subtracting the reference city value from MAAV's value. Since tree match is contingent upon the subject city's species composition, tree matching estimates were not normalized [40]. Normalized values were determined by comparing the difference values on a $0-10$ scale. Next, each normalized value was weighted for importance, based on the study objectives and subject city climate.

To weight the criteria by importance, the normalized values were multiplied by a factor less than 1 . All four factors should add up to 1 [40]. Tree species match was considered to be most significant because analyzing carbon storage and sequestration is the main objective, therefore it was given a factor of 0.4. HDD and CDD reflect building energy heating and cooling loads. While these do affect carbon emissions, Medellin has a fairly mild, consistent climate because of its altitude and proximity to the equator [37]. Because of this, HDD and CDD will have less impact on the results so they were both assigned a factor of 0.2. Annual Precipitation mostly accounts for rainfall interception and was thus assigned a factor of 0.2 [40]. Finally, the root mean square error (RMSE) for each reference city was determined by multiplying the normalized values by their weighted factor and summing the results. The city with the lowest RMSE should be selected as the reference city for the analysis [40]; as such, Honolulu, Hawaii, USA was selected (RMSE $=3.6$ ).

Next, trees in the MAAV inventory are coded by species using i-Tree Streets codes available for the Honolulu reference city. When matches were not available on the species level, the genus level were used. When matches were not available on the genus level, the tree type were used. The inventory of Medellin trees consisted of 358 tree species, of which 121 were modeled using species or genus level parameters. The remaining 237 species were modeled based on tree type characteristics. The study from Morales et al. (2006) [43] was referenced to determine tree types and city characteristics as needed (i.e., city population and study area). These codes along with DBH and tree height were then entered into i-Tree Streets.

After the reference city was selected and the data were coded and entered, $\mathrm{i}$-Tree Streets produced reports of tree costs and benefits, including $\mathrm{CO}_{2}$ storage and sequestration, $\mathrm{CO}_{2}$ equivalent energy savings from shading and cooling, and emissions from maintenance and decomposition. To facilitate the comparison of $\mathrm{CO}_{2}$ sequestration estimates from this study with others, gross and net tree $\mathrm{CO}_{2}$ sequestration per ha was calculated using land area specific to the land use analyzed in the study, or public green space area or street/transportation as reported by the Aburrá Valley Urban Environmental Authority [37]. Since the results from all relevant studies were reported in above and below ground $\mathrm{CO}_{2}$, when necessary, a root-to-shoot-ratio of 0.26 was used to estimate below ground $\mathrm{CO}_{2}$ and a conversion ratio of 3.67 was used to convert carbon to $\mathrm{CO}_{2}$ [14,33]. All reported values for other cities are exclusively for street trees.

\subsection{Estimating Tree Cover, Available Planting Space, and Carbon Offsets}

As an additional metric to assess existing and potential $\mathrm{CO}_{2}$ offsets, tree cover, i.e., the proportion of area covered by tree crowns, was also estimated using two different methods. The first method is based on the field measured individual tree crown diameter measurements [27], and the second method uses the i-Tree Canopy tool [44]; an online aerial image interpretation user interface to estimate tree cover as well as public versus private trees and available planting space.

For the first method, individual tree crown diameters recorded in the final analyzed inventory were used to calculate the crown area for each tree. These were summed and converted to hectares, giving the area of public tree cover, specific for the inventory. In the second method, i-Tree Canopy v6.1 was used to photo interpret tree cover from aerial imagery, and to create four reference land cover classes: (1) Non-Tree (NT; Any area not covered by a tree and not suitable for planting); (2) Public Tree (PubT; Tree crown associated with trees located in all public areas); (3) Private Tree (PT; Tree crown associated with residential, commercial, or private recreation areas); and (4) Available Planting Space (APS; Any area where a tree can be planted and expected to grow to maturity). Private trees were any tree inside residential, commercial, or recreational land uses. A set of 300 random points within the 
study area was generated and displayed and a land cover class was assigned to each point. The area of each cover class was also determined by multiplying the cover class proportion by the total city area.

Using the area of public tree cover given by both methods, net and total $\mathrm{CO}_{2}$ sequestration per $\mathrm{m}^{2}$ of tree cover was determined by dividing net sequestration $\left(\mathrm{CO}_{2} \mathrm{~g}\right)$ and total sequestration (Gross sequestration + emissions avoided from shading minus decomposition minus maintenance emissions) by estimated public tree area $\left(\mathrm{m}^{2}\right)$. This metric allows us to estimate potential $\mathrm{CO}_{2}$ benefits from potentially planting trees in available space and total $\mathrm{CO}_{2}$ benefits from all city trees (public and private) [27]. These were calculated by multiplying $\mathrm{g} \mathrm{CO}_{2}$ per $\mathrm{m}^{2}$ of tree cover by the available planting space area and by the total tree cover area, respectively.

\subsection{Selection and Description of Carbon Emissions Reduction Strategies}

To better assess the results of this study relative to other technological-based solutions, carbon offsets from MAAV street trees were compared to two other reduction sources in the MAAV. Specifically, carbon offsets from the MAAV's new cable car transit system and from two landfill gas (LFG) management projects at landfills accepting waste from the MAAV were used.

In 2004, the first urban aerial cable car public transit system was implemented in the municipality of Medellin. The cable cars use ski-lift technology suited to the sloping streets of the Medellin and its hydroelectric power source [5]. The Metro Company that jointly financed the transit system with the city prepared a Project Design Document (PDD) under the Clean Development Mechanism (CDM) that proposed a methodology to report emissions reductions from the project. Reductions were based on baseline emissions defined as what would have been emitted if other forms of transportation were used [5].

In 2007, the University of Antioquia and Empresas Varias de Medellin (EEVVM) agreed to a landfill gas (LFG) management project at the Curva de Rodas and La Pradera Landfills [45]. The project uses landfill gas recovery systems and enclosed flare combustion stations to capture, flare, and destroy LFGs [4]. Construction at the landfills started in 2008 and in 2009 the UNFCCC registered the project under the CDM with approval from Colombia and the investment country, the United Kingdom [45]. The waste at both landfills comes from the MAAV [4].

These two technology-based solutions were selected because: (1) they both reduce emissions contributable to the MAAV; (2) they were both evaluated under methodologies approved by the UNFCCC under the CDM; and (3) they have publicly available PDDs reporting detailed estimates of offsets. This allows for comparisons within the same study area and emissions scope and provides insights for regional policy makers and investors regarding the viability of nature-based solutions and serves to give context and perspective to our results in terms of carbon offsets.

\section{Results}

\subsection{Urban Tree Carbon Storage and Sequestration}

The total $\mathrm{CO}_{2}$ storage by public trees in the study area was estimated to be $103,820 \mathrm{Mg}$. Gross $\mathrm{CO}_{2}$ sequestration was $2077 \mathrm{Mg} /$ year and the avoided $\mathrm{CO}_{2}$ emissions through energy savings were $5090 \mathrm{Mg}$ /year. Decomposition and maintenance emissions were 332,222 and 122,130 $\mathrm{kg} \mathrm{CO}_{2}$ /year, respectively. Taking all of these sinks and sources into account, public trees in the study area are responsible for $6712 \mathrm{Mg} \mathrm{CO}_{2}$ reductions annually.

Using the first method to find tree cover (crown diameter), public trees covered $4.6 \%$ of the city area. Using the second method (i-Tree Canopy), public trees covered $8.33 \pm 1.60 \%$ of the city area, private trees covered $5.67 \pm 1.33 \%$, and $7.67 \pm 1.54 \%$ was available for tree planting (Table 1). Net sequestration of $\mathrm{CO}_{2}$ per area of tree cover was $320 \mathrm{gCO}_{2} / \mathrm{m}^{2} /$ year using the first tree crown diameter method and $177 \mathrm{gCO}_{2} / \mathrm{m}^{2} /$ year using the i-Tree canopy method (Table 2). Using these results, it was estimated that plantings in available space have the potential to increase net $\mathrm{CO}_{2}$ sequestration by 1606 to $2913 \mathrm{Mg} \mathrm{CO}_{2}$ /year. If avoided emissions from shading and maintenance emissions are also 
accounted for, estimates can increase to 6180 to $11,211 \mathrm{Mg} \mathrm{CO}$ /year. Net $\mathrm{CO}_{2}$ sequestration for all trees, public and private, was estimated to be 2931 to $5318 \mathrm{Mg} \mathrm{CO}_{2}$ /year, respectively (Table 2).

Table 1. Public tree cover and green space characteristics in the urban zone of the Metropolitan Area of the Aburra Valley (MAAV) using two different tree cover estimation methods.

\begin{tabular}{ccc}
\hline & Method 1 (Crown Diameter) & Method 2 (i-Tree Canopy) \\
\hline Public Tree Cover & $4.59 \%$ & $8.33 \% \%^{* *}$ \\
Public Tree Cover Area & $5.45 \mathrm{~km}^{2}$ & $9.88 \mathrm{~km}^{2}$ \\
Public Green Space Area & $21.53 \mathrm{~km}^{2 *}$ & $21.53 \mathrm{~km}^{2}$ \\
Tree Cover in Public Green Spaces & $25.31 \%$ & $45.89 \%{ }^{* *}$ \\
\hline Area reported by the Aburrá Valley Urban Environmental Authority [37]. ${ }^{* *}$ Includes forested public areas.
\end{tabular}

Table 2. $\mathrm{CO}_{2}$ benefits by public trees and potential $\mathrm{CO}_{2}$ benefits in available space using actual tree crown diameters and i-Tree Canopy.

\begin{tabular}{lcc}
\hline & Method 1 (Crown Diameter) & Method 2 (i-Tree Canopy) \\
\hline $\begin{array}{l}\text { Net Sequestration by public trees } \\
\text { per tree cover area }\end{array}$ & $320 \mathrm{~g} \mathrm{CO}_{2} / \mathrm{m}^{2}$ & $177 \mathrm{~g} \mathrm{CO}_{2} / \mathrm{m}^{2}$ \\
\hline $\begin{array}{l}\text { Potential Net Sequestration in } \\
\text { available space }\end{array}$ & $2913 \mathrm{Mg} \mathrm{CO}_{2} /$ year & $1606 \mathrm{Mg} \mathrm{CO}_{2} /$ year \\
\hline $\begin{array}{l}\text { Potential Total } \mathrm{CO}_{2} \text { sequestration } \\
\text { by planting all available spaces }\end{array}$ & $11,211 \mathrm{Mg} \mathrm{CO}_{2} /$ year & $6180 \mathrm{Mg} \mathrm{CO}_{2} /$ year \\
\hline $\begin{array}{l}\text { Total } \mathrm{CO}_{2} \text { Net Sequestration } \\
\text { public and private trees) }\end{array}$ & $5318 \mathrm{Mg} \mathrm{CO}_{2} /$ year & $2931 \mathrm{Mg} \mathrm{CO}_{2} /$ year \\
\hline
\end{tabular}

\subsection{Carbon Benefits by Species}

As shown in Appendix B, the top three tree species that contributed to total public urban forest $\mathrm{CO}_{2}$ sequestration were benjamin fig (Ficus benjamina), the mango tree (Mangifera indica), and the octopus tree (Schefflera actinophylla). Table 3 shows the above and below ground tree $\mathrm{CO}_{2}$ sequestration per ha of public green area for this study and other different cities reported in the literature.

Table 3. Examples of above and below ground public tree $\mathrm{CO}_{2}$ sequestration per ha of public green area in different cities.

\begin{tabular}{|c|c|c|c|}
\hline Study Area & $\mathrm{Kg} \mathrm{CO}_{2} /$ ha/Year * & Method & Reference \\
\hline \multicolumn{4}{|l|}{ Gross sequestration ** } \\
\hline Medellin, Colombia & 965 & i-Tree Streets & This study \\
\hline Barcelona, Spain & 1866 & i-Tree ECO *** & [30] \\
\hline Shenyang, China & 9212 & Allometric Equations from Lit & [34] \\
\hline Bolzano, Italy & 4366 & Allometric Equations from Lit & [17] \\
\hline Average of 35 cities in China & 7927 & Literature & [28] \\
\hline Beijing & 1835 & Allometric Equations from Lit & [29] \\
\hline \multicolumn{4}{|l|}{ Net sequestration $* * * *$} \\
\hline Medellin, Colombia & 869 & i-Tree Streets & This study \\
\hline Gainesville, US & 2573 & i-Tree ECO *** & [14] \\
\hline Miami, US & 855 & i-Tree ECO ${ }^{* * *}$ & [14] \\
\hline Sacramento US & 1200 & Allometric Equations from Lit & [16] \\
\hline
\end{tabular}

${ }^{*}$ Area of public green space or transportation land use; ${ }^{* *}$ The amount of $\mathrm{CO}_{2}$ taken up annually; ${ }^{* * *}$ Includes city-wide public and private urban trees; ${ }^{* * *}$ Sequestration minus $\mathrm{CO}_{2}$ released through decomposition.

\section{3. $\mathrm{CO}_{2}$ Offset Potential and Co-Benefits}

According to Grupo de Investigaciones Ambientales [46], a total of 2,864,090 $\mathrm{Mg} \mathrm{CO}_{2}$ were emitted in the urban zone of the MAAV in 2011, of which 2,587,957 $\mathrm{Mg} \mathrm{CO}_{2}$ were from transportation sources. Net sequestration by the MAAV's existing urban forests, through growth, offsets $0.06 \%$ of the current 
total emissions and $0.07 \%$ of transportation emissions. Accounting for indirect energy effects, urban forests offset $0.23 \%$ and $0.26 \%$ of total and transportation $\mathrm{CO}_{2}$ emissions, respectively. The potential offsets from planting all available planting spaces can however be up to $11,211 \mathrm{Mg} \mathrm{CO}_{2}$ /year (Table 4). The $\mathrm{CO}_{2}$ offset of public trees in the urban zone of the MAAV was similar to that of other studies (Table 5).

The total economic value of the co-benefits provided by the MAAV's public urban trees were 3.5 million US\$ per year or an average of 19 US\$ per tree per year. Model estimates indicate that storm water regulation alone accounted for $35 \%$ of these benefits, while air quality and aesthetics accounted for 5 and 31\%, respectively. Energy savings from tree shading and direct $\mathrm{CO}_{2}$ sequestration through growth accounted for 28 and 1\%, respectively; highlighting the important co-benefit of the cooling effect of trees. We note that these are based on values and benefit transfer values from US cites and the lack of city specific energy use, hydrological runoff, and cost data from the MAAV deem that these estimates be used as approximations.

Table 4. Emission Reductions of Tonnes of $\mathrm{CO}_{2}\left(\mathrm{Mg} \mathrm{CO}_{2}\right)$ from different strategies in the Metropolitan Area of Medellin, Colombia.

\begin{tabular}{|c|c|c|c|}
\hline & & \multicolumn{2}{|c|}{ Emissions ( $\mathrm{Mg} \mathrm{CO} \mathrm{CO}_{2} /$ Year) } \\
\hline & & City Total 2,864,090 & Transportation Sector $2,587,957$ \\
\hline Reduction Source & $\begin{array}{c}\text { Reductions } \\
\left(\mathrm{Mg} \mathrm{CO}_{2} / \text { Year) }\right.\end{array}$ & $\%$ Reductions of Total & $\%$ Reductions of Transport \\
\hline Net trees sequestration & 1744 & $0.06 \%$ & $0.07 \%$ \\
\hline Avoided from cooling & 509 & $0.18 \%$ & $0.20 \%$ \\
\hline Total public tree effects & 6712 & $0.23 \%$ & $0.26 \%$ \\
\hline Landfill Methane Capture & $167,321 *$ & $5.84 \%$ & $6.47 \%$ \\
\hline
\end{tabular}

${ }^{*}$ Tonnes of $\mathrm{CO}_{2}$ equivalent $\left(\mathrm{Mg} \mathrm{CO} \mathrm{CO}_{2}\right) ;{ }^{* *}(\mathrm{Min}=$ Minimum and Max = Maximum).

Table 5. Reported $\mathrm{CO}_{2}$ offsets of the transportation (Transp) sector and city level emission by public trees in different cities.

\begin{tabular}{cccccc}
\hline City & $\begin{array}{c}\text { Gross or Net } \\
\text { Sequestration }\end{array}$ & $\begin{array}{c}\text { Emissions } \\
\text { Source }\end{array}$ & $\begin{array}{c}\text { Reported Emissions * } \\
\left(\mathbf{M g ~ C O}_{\mathbf{2}} \mathbf{)}\right.\end{array}$ & Offset (\%) & Reference \\
\hline MAAV, Colombia & Gross & Transp *** & $2,587,957$ & $0.08 \%$ & This Study \\
Bolzano, Italy & Gross & Transp & 300 & $0.10 \%$ & {$[17]$} \\
MAAV, Colombia & Net & City*** & $2,864,090$ & $0.06 \%$ & This Study \\
Barcelona, Spain & Net & City & $4,053,766 * *$ & $0.02 \%$ & {$[30]$} \\
Gainesville, US & Net & City & $2,097,627 * *$ & $0.16 \%$ & {$[14]$} \\
Miami, US & Net & City & $31,967,000 * *$ & $0.07 \%$ & {$[14]$} \\
\hline
\end{tabular}

\section{Discussion}

\subsection{Comparison of Urban Forest Carbon Sequestration Across Cities}

Although growth rates associated with a tropical climate are expected to be higher, sequestration by public trees in the urban zone of the MAAV had relatively lower $\mathrm{CO}_{2}$ sequestration than what was reported for other cities (Table 5). The largest difference was with gross sequestration reported for "road forests" in Shenyang, China [34]. Road forests are defined as trees along railroads, highways, boulevards, roads, and streets. Gross sequestration for Shenyang was almost 10 times that found for the MAAV. One contributing factor could be the higher tree density in Shenyang road forests $\left(27,900\right.$ trees $\left./ \mathrm{km}^{2}\right)$ than in the MAAV $\left(8400\right.$ trees $\left./ \mathrm{km}^{2}\right)$, possibly due to a tree planting project five years before the city was surveyed in which 19 million trees were planted [34]. The authors also highlighted that fast-growing tree species contributed to high net sequestration rates. Conversely, they noted that road forests had slower growing species than other land types evaluated [34]. 
For net sequestration, the urban zone of the MAAV had a value very similar to trees associated with transportation land use in Miami, but much lower than in Gainesville in the US [14] (Table 3). This observation may be due to tree density and growth rates. Miami had a lower tree density $\left(3800\right.$ trees $\left./ \mathrm{km}^{2}\right)$ for transportation trees than Gainesville $\left(15,100\right.$ trees $\left./ \mathrm{km}^{2}\right)$ and the MAAV, but had high net sequestration rates per tree, most likely due to a more tropical climate than Gainesville [14]. Higher net sequestration by transportation trees in Gainesville than the MAAV is most likely due to higher tree density.

\subsection{Carbon Offset in Medellin}

To better understand how well public trees offset $\mathrm{CO}_{2}$ emissions, offset estimates in the urban zone of the MAAV were compared to two other carbon offset strategies used for the MAAV: cable car public transportation and improved landfill gas management (Table 4). The PDD for the cable car strategy reported total reductions of 121,029 $\mathrm{Mg} \mathrm{CO}_{2} \mathrm{e}$ from 2010 to 2016, averaging 17,290 $\mathrm{Mg} \mathrm{CO}_{2} \mathrm{e}$ /year [47]. Based on this average annual reduction rate, $0.60 \%$ of the urban zone of the MAAV's total $\mathrm{CO}_{2}$ emissions and $0.67 \%$ of its transportation $\mathrm{CO}_{2}$ emissions were offset. The PDD for the landfill projects reported 1,171,245 $\mathrm{Mg} \mathrm{CO}_{2}$ e reductions over the crediting period from 2008 to 2015, averaging $167,321 \mathrm{Mg} \mathrm{CO}_{2} \mathrm{e} /$ year [4]. This offsets $5.84 \%$ of the urban zone of the MAAV's total $\mathrm{CO}_{2}$ emissions and $6.47 \%$ of its transportation $\mathrm{CO}_{2}$ emissions.

Comparing the offset potential of the different strategies, current public trees were not as effective as the cable cars or landfills. Avoided emissions from cooling must be considered for public tree offsets to be close to cable car offsets, and even then they are still lower. The two-landfill methane capture systems were significantly more effective than both the cable cars and the public trees, most likely due to the high global warming potential of methane compared to $\mathrm{CO}_{2}$. However, if available planting space is considered, carbon offsets become more competitive with cable cars, although they are still far from methane capture (Table 4). Here we only analyzed $\mathrm{CO}_{2}$ offset by urban public trees. Nevertheless, including other existing trees in public forests and private urban lands as well as carbon pools from urban soils in green spaces, the offsets would have been higher.

Another consideration when comparing such strategies to nature-based solutions are socio-economic and environmental co-benefits beyond climate change mitigation. Urban forests have been documented to provide a variety of important ecosystem services, ranging from environmental to economic to social (e.g., [48]). Some co-benefits from urban forests include atmospheric air pollution removal, property price premiums, recreation opportunities, temperature amelioration, and overall quality of life $[9,48]$. Both public trees and the cable cars have been studied under the lens of social equity. In Bogota, Colombia, for example, it was found that the distribution of ecosystem services from public trees was unequal across socio-economic rankings [9]. Management goals for public trees can address this inequity for added social benefits. Nevertheless, Medellin's cable cars also have co-benefits that can improve social equity such as cheap transportation options and even decreased crime [5,49]. However, methane capture in/by landfills serves a single purpose.

While this study focuses on the carbon offset potential for different strategies, economic efficiency largely influences what mitigation approach a government, business, or non-governmental organization may take. Costs and benefits of urban tree plantings as well as the current price of carbon credits in market schemes affect the economic attractiveness of urban forest initiatives. McPherson et al. (2005) [18] analyzed the costs and benefits of public trees in five of the reference US cities for i-Tree Streets (Fort Collins, Colorado; Cheyenne, Wyoming; Bismarck, North Dakota; Berkeley, California; and Glendale, Arizona). While this study only examined US cities, it shows that urban plantings may be economically favorable, especially when accounting for added co-benefits and as such are a viable nature-based solution. McHale et al. (2007) [15] found that the cost per $\mathrm{Mg} \mathrm{CO}_{2} \mathrm{e}$ (one credit), including avoided emissions from cooling, was $\$ 145.10$ to $\$ 647.26$, while the market price at the time ranged from $\$ 3$ to $\$ 13$ per credit, and that projects in climates with higher sequestration rates would be more cost effective [15]. 
Although recent studies and reviews on the use of nature-based solutions have discussed in great detail their potential and application in the European Union and its temperate climates, these discussions have all but excluded their application in Neotropical cities of the developing world [12,13]. Indeed, given the interdisciplinary focus and multiple functions of the nature-based solution approach in addressing not only climate change but other socio-economic problems, such an approach by definition is more warranted in tropical regions of Latin America and Asia where access to resources, employment, green spaces, and quality of life is often inequitable $[7,9,17]$. Such an approach is also in line with the recent United Nation's Sustainable Development Goals (Goal 11) of making, "cities inclusive, safe, resilient and sustainable" [50].

\subsection{Limitations of the Modeling Approach}

We note that most urban forest functional models such as i-Tree Streets will have sources of error. The possibility of $\mathrm{CO}_{2}$ storage estimate errors of up to $40 \%$ for i-Tree Streets versus i-Tree Eco have been reported [33]. Another study found $\mathrm{CO}_{2}$ sequestration estimates by i-Tree Streets are often $49 \%$ higher than that estimated using site and species specific growth rates and allometric equations [51].

A noteworthy shortcoming of i-Tree Streets is that all tree growth, mortality, and age-C relationships are derived from US cities. Thus, the model does not directly use site or species-specific tree growth or mortality rates [39,41]; therefore, the results presented in this study should be interpreted with care. Bare and Ashton [52] did determine a mean annual DBH increment of $1.0 \mathrm{~cm}$ for multiple, open-grown, species in a monitored restoration project in nearby Ebejico, Antioquia, Colombia. However, we know of no other comparable studies of tropical urban tree growth rates in Colombia or northern South America. Urban tree growth rates for larger trees in the North American subtropics have been found to range from an average of $1.1 \mathrm{~cm}$ per year in Gainesville, USA to $0.98 \mathrm{~cm}$ per year in San Juan, Puerto Rico [53,54]. While using a systematic process to choose the most appropriate reference city that accounts for different regional factors minimizes this error, applying US data to a different country still limits the accuracy of the results [40]. For this study, using the reference city with the highest tree match still left $29 \%$ of trees in the inventory without a species or genus specific code.

Another factor behind many of our reported limitations for i-Tree Streets is the lack of allometric equations specifically developed for urban trees in the neotropics, but also in other tropical and temperate cities. When urban tree derived equations are not available, i-Tree models use forest derived equations with adjustments to better reflect an urban environment [55]. Whenever an adjustment or substitute is used in modeling, results become less accurate. An average of $127-282 \mathrm{~kg} \mathrm{CO}_{2}$ per tree (Appendix B) were estimated for the MAAV, which is well below the $580-1260 \mathrm{~kg} \mathrm{CO} 2$ per tree found in Bogota, Colombia, [9] when adjusting for below ground carbon stocks and using allometric equations. Thus, the use of different models will affect the results [33]. That said, the i-Tree Streets model has been used internationally [41] and because of the minimum number of variables required, we propose that this makes its use appropriate for data poor, low income cities. In this work, the proposal of a characterization framework for nature-based solutions also acknowledges the need for improved carbon estimation for assessing the multiple co-benefits of these approaches [21].

An additional limitation of $\mathrm{i}$-Tree Streets that was observed during our analysis is that it assumes that every street tree has some effect on building cooling. However, street trees are often located away from buildings. Future studies need to more accurately measure avoided emissions from cooling using additional factors such as the cardinal direction of a tree relative to a building, climate, deciduous or evergreen, and percent cover of buildings and trees in a plot [14].

The two methods used to estimate tree cover values, measured tree crown area and i-Tree Canopy, produced fairly different results. I-Tree Canopy reported almost twice as much tree cover than using the average crown area. Multiple factors could have caused this: (1) trees with a DBH $<2.50 \mathrm{~cm}$ and a total height $<2 \mathrm{~m}$ were filtered out and thus were not included in the average crown area method, whereas the i-Tree Canopy method could not discriminate among trees' structural characteristics; (2) The georeferenced boundaries of the study area imported into i-Tree Canopy included areas on the 
outskirts of the urban area that consequently may have higher tree cover and more available planting space; (3) Trees inaccessible for measurement when the inventory was taken, as well as the 352 trees with no species data removed from the study were not accounted for with the crown area method. Because of these factors, the crown area method most likely underestimated tree cover while i-Tree Canopy most likely overestimated tree cover and available planting space. However, we posit that both values represent a range of reasonable minimum-maximum values for the $\mathrm{CO}_{2}$ offset potential (Table 4).

In general, care is warranted when making comparisons between offset potentials, as many different factors influence it, such as the scope of the emissions. For example, Barcelona, Spain, had a gross $\mathrm{CO}_{2}$ sequestration rate per ha almost twice that of the MAAV (Table 5). However, the MAAV has an offset proportion three times that of Barcelona. This does not necessarily mean the MAAV's public trees offset more than Barcelona's public trees. One reason for a lower offset potential in the Spanish city is that emissions were reported in $\mathrm{Mg} \mathrm{CO}_{2} \mathrm{e}$, not only $\mathrm{CO}_{2}$, i.e., additional greenhouse gases were accounted for in the calculations. For the urban zone of the MAAV, transportation emissions of 2,587,957 $\mathrm{Mg} \mathrm{CO}_{2}$ and total emissions of 2,864,090 $\mathrm{Mg} \mathrm{CO}_{2}$ for 2011 were used [46]. Nevertheless, the comparisons do show that MAAV's public trees offset a comparable amount of $\mathrm{CO}_{2}$ to other cities in other studies, like Gainesville, US and Barcelona, Spain.

\section{Conclusions}

The use of a nature-based solutions approach for addressing climate change and other environmental and socio-economic problems has only recently been proposed in the scientific literature in the form of perspective pieces and in the European Union context. Noticeably missing from this discourse, are: (1) Evidence based examples of such strategies and solutions; (2) Data, information, tools, and models for documenting, monitoring, modeling, and assessing such solutions; and (3) examples from the developing world where such approaches can have a likely greater impact in providing more effective, sustainable, and equitable solutions. To these ends, although the urban ecosystem service and green infrastructure approach is used in Latin America, this study provides one of the first insights into the role of greening of neotropical cities, via tree planting programs, as a viable nature-based solution strategy.

Although urban forests, as a nature-based solution, provide many co-benefits; developing more accurate and region-specific methods and models for estimating carbon offsets by urban forests can help improve access to international funding for these types of nature based solution projects. Urban forests may also be incorporated into carbon markets on national or regional scales. The Climate Action Reserve, the carbon offset registry for the North American carbon market, has approved two protocols for urban forest projects: Urban Tree Plantings and Urban Tree Management. Both protocols only account for standing carbon; avoided emissions from cooling and maintenance emissions are not counted.

The consideration of nature-based air quality, socio-economics, biodiversity, and in particular $\mathrm{CO}_{2}$ benefits from public trees can help guide management of these natural resources and the use of public space. As a potential carbon offset strategy, public tree plantings were competitive but less effective than other strategies in the region. Accounting for additional ecosystem services and social equity benefits may increase the favorability of tree plantings as a nature-based solution to the challenges of urbanization. Future studies could take a more holistic approach, assessing the economic feasibility and social acceptability of public tree plantings for the MAAV. More regional data and biomass equations based on urban trees as opposed to forest trees can improve the measurement of costs and benefits. Additionally, revising methods of selecting reference cities to better reflect the closest match could help to minimize the error associated with regional differences. Further studies on urban forests in low-middle income countries, especially in regions with rapid growth rates, are needed for improved urban planning and potential international investment in nature-based solutions. 
Acknowledgments: We would like to especially thank Claudia Helena Hoyos E. from the Área Metropolitana del Valle de Aburrá, for providing us access to the tree inventory data. We also thank Hector Restrepo and Flavio Moreno, Universidad Nacional de Colombia, Medellín, for helping us access spatial data and local contacts. We are also grateful to Marcela Alejandra Sierra Vásquez from the Área Metropolitana del Valle de Aburrá for assistance with metadata questions and issues concerning the spatial data sets. Funds for covering the costs to publish in open access were provided by the Dirección de Investigación e Innovación of the Universidad del Rosario.

Author Contributions: C.R. and F.E. conceived and designed the experiments; C.R. performed the experiments; C.R., J.Z., and N.C. analyzed the data; C.R., F.E., and N.C. wrote the paper.

Conflicts of Interest: The authors declare no conflict of interest. The founding sponsors had no role in the design of the study; in the collection, analyses, or interpretation of data; in the writing of the manuscript, and in the decision to publish the results.

\section{Appendix A}

Table A1. Criteria for Selecting a Reference City for Medellin, Colombia and the Values used to Calculate Root Mean Square Error (131).

\begin{tabular}{cccccc}
\hline Matching Criteria & Medellin & Honolulu & Modesto & Orlando & Santa Monica \\
\hline Species Match \% (Method 1) & & $13 \%$ & $29 \%$ & $0 \%$ & $12 \%$ \\
Species Match \% (Method 2) & & $71 \%$ & $12 \%$ & $43 \%$ & $29 \%$ \\
Species Match \% (Method 2, Normalized) & & 2.92 & 8.84 & 5.70 & 7.06 \\
Heating Degree Days (Base 18 ${ }^{\circ}$ C) & 40 & 0 & 2746 & 644 & 265 \\
Difference * & & 40 & 2706 & 604 & 225 \\
Normalized & 1625 & 0.09 & 6.22 & 1.39 & 0.52 \\
Cooling Degree Days (Base 18 ${ }^{\circ}$ C) & & 2526 & 597 & 310 & 1891 \\
Difference & & 901 & 1028 & 1315 & 266 \\
Normalized & 1687 & 3.63 & 4.14 & 5.30 & 1.07 \\
Annual Precipitation (mm) & & 392 & 315 & 1367 & 570 \\
Difference & & 1295 & 1372 & 320 & 1117 \\
Normalized & & 3.56 & 9.07 & 2.11 & 7.38 \\
\end{tabular}

* Difference between the Medellin criteria value and the reference city criteria value (ex. HDD difference value for Honolulu is $40-0=40$ ).

\section{Appendix B}

Table A2. Tree species in the Medellin Metropolitan Area, Colombia with the greatest $\mathrm{CO}_{2}$ sequestration by total, density, and per tree.

\begin{tabular}{ccc}
\hline Species & Total $\mathbf{~ g ~ C O}_{2} /$ Year & Trees/km ${ }^{2}$ Public Area \\
\hline Ficus benjamina & $1,094,837$ & 430 \\
Mangifera indica & 758,928 & 510 \\
Schefflera actinophylla & 531,587 & 160 \\
Spathodea campanulata & 469,975 & 490 \\
Persea americana & 361,534 & 360 \\
Terminalia catappa & 226,665 & 680 \\
Pithecellobium dulce & 217,114 & 610 \\
Araucaria heterophylla & 156,275 & 110 \\
Psidium guajava & 128,067 & 200 \\
Erythrina species & 127,246 & 200 \\
\hline Tree Species or Type & Average $\mathbf{K g ~ C O} \mathbf{O}_{2} /$ Tree/Year & \\
Ficus carica & 282 & \\
Pimenta racemosa & 239 & \\
Manilkara zapota & 220 & \\
Broadleaf Evergreen Large & 169 & \\
Melia azedarach & 159 & \\
Schefflera actinophylla & 159 & \\
Erythrina variegata & 156 & \\
Persea americana & 152 & \\
Calophyllum inophyllum & 132 & \\
Podocarpus species & 127 & \\
\hline
\end{tabular}




\section{References}

1. Department of Economic and Social Affairs, Population Division. World Population Prospects: The 2015 Revision, Key Findings and Advance Tables; Working Paper No. ESA/P/WP.241; United Nations: New York, NY, USA, 2015; p. 59.

2. Department of Economic and Social Affairs, Population Division. World Urbanization Prospects: The 2014 Revision, Highlights; Working Paper No. ST/ESA/SER.A/352; United Nations: New York, NY, USA, 2014; p. 27.

3. Blackman, A.; Morgenstern, R.D.; Murcia, L.M.; Garcia de Brigard, J.C. Review of the Efficiency and Effectiveness of Colombia's Environmental Policies. 2006. Available online: http://www.rff.org/files/ sharepoint/WorkImages/Download/RFF-Rpt-ColoEPEfficiency.pdf (accessed on 4 May 2017).

4. Curva de Rodas and la Pradera Landfill Gas Management Project, Version 3. 2006. Available online: http:/ / www.voksenaasen.no/wp-content/uploads/2016/08/Prosjektinfo_-CDM-2183_Curva-deRodas-and-La-Pradera-landfill-gas-management-project.pdf (accessed on 4 May 2017).

5. Dávila, J.D.; Daste, D. Medellin's Aerial Cable-Cars: Social Inclusion and Reduced Emissions. UNEP-IPSRM Cities, Decoupling and Urban Infrastructure. 2012. Available online: https:/ /www.gov.uk/dfid-researchoutputs/medellin-s-aerial-cablecars-social-inclusion-and-reduced-emissions (accessed on 4 May 2017).

6. Bustamante, M.M.C.; Roitman, I.; Aide, T.M.; Alencar, A.; Anderson, L.O.; Aragão, L.; Asner, G.P.; Barlow, J.; Berenguer, E.; Chambers, J.; et al. Toward an integrated monitoring framework to assess the effects of tropical forest degradation and recovery on carbon stocks and biodiversity. Glob. Chang. Biol. 2016, 22, 92-109. [CrossRef] [PubMed]

7. Clerici, N.; Rubiano, K.; Abd-Elrahman, A.; Posada Hoestettler, J.; Escobedo, F. Estimating aboveground biomass and carbon stocks in periurban andean secondary forests using very high resolution imagery. Forests 2016, 7, 138. [CrossRef]

8. Christ, R. ADP technical expert meeting: Urban environment; Statement by Renate Christ. In Proceedings of the Bonn Climate Change Conference, Bonn, Germany, 10 June 2014; IPCC Secretariat: Geneva, Switzerland, $2014 ;$ p. 2.

9. Escobedo, F.J.; Clerici, N.; Staudhammer, C.L.; Corzo, G.T. Socio-ecological dynamics and inequality in bogotá, colombia's public urban forests and their ecosystem services. Urban For. Urban Green. 2015, 14, 1040-1053. [CrossRef]

10. European Commission. Debrief: European Conference "Re-Naturing Cities: Addressing Environmental Challenges and Effects of the Economic Crisis through Nature-Based Solutions", Re-Naturing Cities: Addressing Environmental Challenges and Effects of the Economic Crisis through Nature-Based Solutions; European Commission: Brussels, Belgium, 2014; p. 4.

11. Santiago Fink, H. Human-nature for climate action: Nature-based solutions for urban sustainability. Sustainability 2016, 8, 254. [CrossRef]

12. Kabisch, N.; Frantzeskaki, N.; Pauleit, S.; Naumann, S.; Davis, M.; Artmann, M.; Haase, D.; Knapp, S.; Korn, H.; Stadler, J. Nature-based solutions to climate change mitigation and adaptation in urban areas: Perspectives on indicators, knowledge gaps, barriers, and opportunities for action. Ecol. Soc. 2016, 21, 39. [CrossRef]

13. Nesshöver, C.; Assmuth, T.; Irvine, K.N.; Rusch, G.M.; Waylen, K.A.; Delbaere, B.; Haase, D.; Jones-Walters, L.; Keune, H.; Kovacs, E.; et al. The science, policy and practice of nature-based solutions: An interdisciplinary perspective. Sci. Total Environ. 2017, 579, 1215-1227. [CrossRef] [PubMed]

14. Escobedo, F.; Varela, S.; Zhao, M.; Wagner, J.E.; Zipperer, W. Analyzing the efficacy of subtropical urban forests in offsetting carbon emissions from cities. Environ. Sci. Policy 2010, 13, 362-372. [CrossRef]

15. McHale, M.R.; Gregory McPherson, E.; Burke, I.C. The potential of urban tree plantings to be cost effective in carbon credit markets. Urban For. Urban Green. 2007, 6, 49-60. [CrossRef]

16. McPherson, E.G. Atmospheric carbon dioxide reduction by sacramento's urban forest. J. Arboric. 1998, 24, 215-223.

17. Russo, A.; Escobedo, F.J.; Timilsina, N.; Zerbe, S. Transportation carbon dioxide emission offsets by public urban trees: A case study in Bolzano, Italy. Urban For. Urban Green. 2015, 14, 398-403. [CrossRef]

18. McPherson, G.; Simpson, J.R.; Peper, P.J.; Maco, S.E.; Xiao, Q. Municipal forest benefits and costs in five US cities. J. For. 2005, 103, 411-416. 
19. Yang, J.; McBride, J.; Zhou, J.; Sun, Z. The urban forest in beijing and its role in air pollution reduction. Urban For. Urban Green. 2005, 3, 65-78. [CrossRef]

20. Horn, J.; Escobedo, F.J.; Hinkle, R.; Hostetler, M.; Timilsina, N. The role of composition, invasives, and maintenance emissions on urban forest carbon stocks. Environ. Manag. 2015, 55, 431-442. [CrossRef] [PubMed]

21. Xing, Y.; Jones, P.; Donnison, I. Characterisation of nature-based solutions for the built environment. Sustainability 2017, 9, 149. [CrossRef]

22. Government of Colombia. Colombia Indc Unofficial Translation Eng; UNFCCC Secretariat: Bonn, Germany, 2015; p. 10.

23. UNFCCC. Methodologies for Afforestation and Reforestation (a/r) cdm Project Activities. In Clean Development Mechanism Methodology Booklet, 8th ed.; UNFCCC: New York, NY, USA, 2012; p. 265.

24. CDM Afforestation and Reforestation Working Group. Simplified Baseline and Monitoring Methodologies for Small-Scale a/r cdm Project Activities Implemented on Grasslands or Croplands with Limited Displacement of Pre-Project Activities, Version 2; UNFCCC Secretariat: Bonn, Germany, 2008; p. 20.

25. Nickerson, J. Urban Tree Planting: Project Protocol; Climate Action Reserve: Los Angeles, CA, USA, $2014 ;$ p. 41.

26. Nowak, D.J.; Greenfield, E.J.; Hoehn, R.E.; Lapoint, E. Carbon storage and sequestration by trees in urban and community areas of the united states. Environ. Pollut. 2013, 178, 229-236. [CrossRef] [PubMed]

27. McPherson, E.G.; Xiao, Q.; Aguaron, E. A new approach to quantify and map carbon stored, sequestered and emissions avoided by urban forests. Landsc. Urban Plan. 2013, 120, 70-84. [CrossRef]

28. Chen, W.Y. The role of urban green infrastructure in offsetting carbon emissions in 35 major chinese cities: A nationwide estimate. Cities 2015, 44, 112-120. [CrossRef]

29. Tang, Y.; Chen, A.; Zhao, S. Carbon storage and sequestration of urban street trees in Beijing, China. Front. Ecol. Evol. 2016, 4, 53.

30. Baró, F.; Chaparro, L.; Gómez-Baggethun, E.; Langemeyer, J.; Nowak, D.J.; Terradas, J. Contribution of ecosystem services to air quality and climate change mitigation policies: The case of urban forests in barcelona, spain. AMBIO 2014, 43, 466-479. [CrossRef] [PubMed]

31. Gratani, L.; Varone, L.; Bonito, A. Carbon sequestration of four urban parks in rome. Urban For. Urban Green. 2016, 19, 184-193. [CrossRef]

32. Davies, Z.G.; Dallimer, M.; Edmondson, J.L.; Leake, J.R.; Gaston, K.J. Identifying potential sources of variability between vegetation carbon storage estimates for urban areas. Environ. Pollut. 2013, 183, 133-142. [CrossRef] [PubMed]

33. Timilsina, N.; Staudhammer, C.L.; Escobedo, F.J.; Lawrence, A. Tree biomass, wood waste yield, and carbon storage changes in an urban forest. Landsc. Urban Plan. 2014, 127, 18-27. [CrossRef]

34. Liu, C.; Li, X. Carbon storage and sequestration by urban forests in Shenyang, China. Urban For. Urban Green. 2012, 11, 121-128. [CrossRef]

35. Zhao, M.; Kong, Z.-H.; Escobedo, F.J.; Gao, J. Impacts of urban forests on offsetting carbon emissions from industrial energy use in hangzhou, china. J. Environ. Manag. 2010, 91, 807-813. [CrossRef] [PubMed]

36. Kroeger, T.; Escobedo, F.J.; Hernandez, J.L.; Varela, S.; Delphin, S.; Fisher, J.R.; Waldron, J. Reforestation as a novel abatement and compliance measure for ground-level ozone. Proc. Natl. Acad. Sci. USA 2014, 111, E4204-E4213. [CrossRef] [PubMed]

37. Área Metropolitana del Valle de Aburrá-AMVA. Plan Maestro de Espacios Públicos Verdes Urbanos de la Región Metropolitana del Valle de Aburrá; Consultoría Colombiana-CONCOL and Arredondo \& Madrid-AIM: Bogotá, Colombia, 2006.

38. Flavio Moreno Hurtado, C.H.H.E. Guía Para el Manejo del Arbolado Urbano en el Valle de Aburrá; Área Metropolitana del Valle de Aburrá and Universidad Nacional de Colombia: Bogotá, Colombia, 2015.

39. Estrada, C.H.H. Manejo Integral del Arbolado Urbano en el Valle de Aburra; Area Metropolitana Valle de Aburra \& Universidad Nacional de Colombia: Medellin, Colombia, 2013; p. 65.

40. McPherson, E.G. Selecting reference cities for i-tree streets. Arboric. Urban For. 2010, 36, 230-240.

41. Soares, A.L.; Rego, F.C.; McPherson, E.; Simpson, J.; Peper, P.; Xiao, Q. Benefits and costs of street trees in Lisbon, Portugal. Urban For. Urban Green. 2011, 10, 69-78. [CrossRef]

42. i-Tree. i-Tree Software Suite User's Manual, 4th ed. 2009. Available online: https://www.itreetools.org/ resources/manuals/i-Tree\%20Vue\%20Users\%20Manual.pdf (accessed on 5 May 2017). 
43. Leon Morales, T.V. Árboles Ornamentales en el Valle de Aburrá: Elementos de Manejo; Área Metropolitana: Medellín, Colombia, 2006; p. 339.

44. i-Tree. i-Tree Canopy Technical Notes. 2011. Available online: https://canopy.itreetools.org/resources/ iTree_Canopy_Methodology.pdf (accessed on 5 May 2017).

45. Global Methane Initiative. International Best Practice Guide for Landfill Gas Energy Projects: Appendix A, Case Studies. Available online: http://www.globalmethane.org/documents/toolsres_lfg_IBPGAppendixA. pdf (accessed on 15 March 2016).

46. El Grupo de Investigaciones Ambientales (GIA). Modeam. Available online: http://modemed. upb.edu.co/zigma2/index.php?option=com_content\&view=category\&id=96\&Itemid=602 $($ accessed on 23 January 2016).

47. CDM Executive Borad. Cable Cars Metro Medellín, Colombia; UNFCCC Secretariat: Bonn, Germany, 2006; p. 72.

48. Gatrell, J.D.; Jensen, R.R. Growth through greening: Developing and assessing alternative economic development programmes. Appl. Geogr. 2002, 22, 331-350. [CrossRef]

49. Hylton, F. Medellín's Makeover. New Left Review 44. 2007. Available online: https://newleftreview.org/II/ 44/forrest-hylton-remaking-medellin (accessed on 9 May 2017).

50. United Nations General Assembly. Transforming Our World: The 2030 Agenda for Sustainable Development; United Nations General Assembly: London, UK, 2015; p. 35.

51. Boukili, V.K.; Bebber, D.P.; Mortimer, T.; Venicx, G.; Lefcourt, D.; Chandler, M.; Eisenberg, C. Assessing the performance of urban forest carbon sequestration models using direct measurements of tree growth. Urban For. Urban Green. 2017. [CrossRef]

52. Bare, M.C.; Ashton, M.S. Growth of native tree species planted in montane reforestation projects in the Colombian and Ecuadorian Andes differs among site and species. New For. 2016, 47, 333-355. [CrossRef]

53. Lawrence, A.B.; Escobedo, F.J.; Staudhammer, C.L.; Zipperer, W. Analyzing growth and mortality in a subtropical urban forest ecosystem. Landsc. Urban Plan. 2012, 104, 85-94. [CrossRef]

54. Lima, J.M.T.; Staudhammer, C.L.; Brandeis, T.J.; Escobedo, F.J.; Zipperer, W. Temporal dynamics of a subtropical urban forest in San Juan, Puerto Rico, 2001-2010. Landsc. Urban Plan. 2013, 120, 96-106. [CrossRef]

55. Fairman, T.A.; Livesley, S.J.; Summers, J.; Shears, I.; Pohls, O. Using Stratum to Estimate the Benefits of Street Trees in Melbourne, Victoria; University of Melbourne: Parkville, Australia, 2010. 